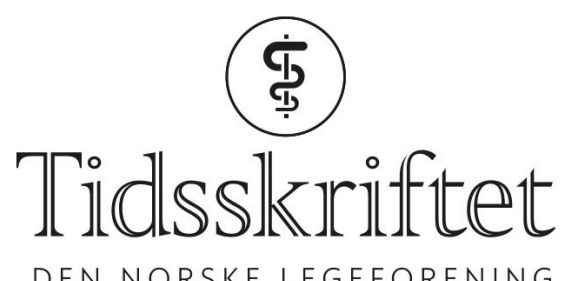

DEN NORSKE LEGEFORENING

\title{
En unik mulighet!
}

KOMMENTAR

\section{$\varnothing$ YVIND HOLME}

E-post: oyvind.holme@sshf.no

Øyvind Holme er nestleder i norsk gastroenterologisk forening og overlege ved seksjon for fordøyelsessykdommer, Sørlandet sykehus Kristiansand.

Ingen oppgitte interessekonflikter.

\section{BIRGITTE SEIP}

Birgitte Seip er leder i norsk gastroenterologisk forening og seksjonsoverlege ved seksjon for fordøyelsessykdommer, Sykehuset i Vestfold.

Ingen oppgitte interessekonflikter.

I likhet med kreftregisterets direktør, Giske Ursin, sier vi oss også enig med Kalager \& Stoltenberg: Tarmkreftscreening må innføres randomisert. Kun på den måten kan vi få valid kunnskap om effekten av screeningprogrammet i Norge.

Det er ingen i dag som vet hva som er den beste screeningmåten for tarmkreft. Hver test har sine styrker og svakheter. Er man riktig uheldig, kan man risikere å innføre en screeningmetode som gir dårlig eller ingen effekt hos enkelte grupper, slik som tilfellet er for sigmoideoskopiscreening hos eldre kvinner (1). I slike tilfeller vil man kun sitte igjen med kostnader og komplikasjoner, men ingen positiv effekt av screeningprogrammet. Når kunnskapsgrunnlaget er svakt, har myndighetene et ekstra ansvar for å sikre at helsekroner brukes riktig. Dette kan enkelt gjøres ved å innføre et helsetilbud randomisert.

Et screeningprogram må evalueres. Er effekten så stor som vi trodde? Står kostnadene i rimelig forhold til innsatsen? Hvis hele befolkningen får det samme tilbudet, blir det vanskelig å evaluere programmet. Det finnes ikke lenger en kontrollgruppe, og vi får aldri vite hvilken test som gir størst kostnad-nytte-effekt. I tillegg kommer nye tester til. Om disse er vesentlig bedre enn den gamle kan være usikkert, og uttesting må foregå kontrollert, slik at befolkningen kan få det beste helsetilbudet.

Norske myndigheter har en unik mulighet ved innføring av tarmkreftscreening. Vi håper sjansen ikke skusles bort.

\section{LITTERATUR:}

1. Holme $\emptyset$, Schoen RE, Senore $C$ et al. Effectiveness of flexible sigmoidoscopy screening in men and women and different age groups: pooled analysis of randomised trials. BMJ 2017; 356: i6673.

[PubMed][CrossRef] 
Publisert: 21. august 2017. Tidsskr Nor Legeforen. DOI: 10.4045/tidsskr.17.0577 (C) Tidsskrift for Den norske legeforening 2020. Lastet ned fra tidsskriftet.no 